\title{
Pulses Production and Productivity: Status, Potential and Way Forward for Enhancing Farmers Income
}

\author{
Ambreesh Singh Yadav ${ }^{1}$, Sujit Kumar ${ }^{1}$, Narendra Kumar ${ }^{2}$ and Hardev Ram $^{3}$ \\ ${ }^{1}$ U.P. Council of Agricultural Research, Lucknow, U.P., 226010, India \\ ${ }^{2}$ Crop Production Division, ICAR-Indian Institute of Pulses Research, \\ Kanpur, U.P., 208024, India \\ ${ }^{3}$ Agronomy Section, ICAR- National Dairy Research Institute, Karnal, \\ Haryana, 132001, India
}

*Corresponding author

\begin{abstract}
Keywords
Pulses,

Productivity, Farmers Income, Yield

Article Info

Accepted:

17 March 2019

Available Online:

10 April 2019 importer of pulses in the world. It has been projected that $32.0 \mathrm{M}$. tones of total pulse requirement for the burgeoning population of India, which will grow to 1.69 billion by 2050. To attain upto this level an annual growth rate of $2.2 \%$ is required. The demand for pulses continues to grow at $2.8 \%$ per annum. Although challenges are diverse including climate changing scenario, decreasing land and water resources, this target is not unattainable. Increasing the average productivity of pulses to $>1200 \mathrm{~kg} \mathrm{ha}^{-1}$ and bringing an additional area of about 3.5 M. ha. under pulses cultivation will be a concrete step in this direction. Enhancement of yield through development of input responsive varieties with multiple resistances to diseases and insect-pests, short duration varieties that fit well in different cropping systems and climate resilient varieties of pulses will be enormously helpful in a vertical expansion of pulses in the country. Similarly, development of new plant types for different agro-climatic situations, and development of photo-thermo insensitive cultivars in crops like urdbean and moongbean will help expanding the areas of these crops in the non-traditional areas of the country.
\end{abstract}

A B S T R A C T

Pulses are important for the nutritional security point of view of the cereal based vegetarian diet of large scale of country. India is the largest producer, consumer and

\section{Introduction}

Pulses are rich source of protein (20 to $25 \%$ ) ability to fix atmospheric nitrogen $(30-150 \mathrm{~kg}$ $\mathrm{ha}^{-1}$ ) and consistent source of income and employment to small and marginal farmers; and thus hold a premier position in the world agriculture [1]. The United Nations declared 2016 as "International Year of pulses" with the objectives of increasing production and consumption of pulses by $10 \%$ by 2020 and creating awareness of benefits of pulses by utilizing social media. In India, pulses constitute a group of 12 crops that include 
mainly chickpea pigeonpea (Cajanus cajan L.), chickpea (Cicer arietinum L.), mungbean (Vigna radiata L. Wilczek), urdbean (Vigna mungo L. Hepper), lentil (Lens culinaris L.) and fieldpea (Pisum sativum L.). India is the largest producer of pulses contributing $25.7 \%$ to the world production [3].

Since more than $80 \%$ of the area under pulses is under stressed rainfed environment, the quality seed of improved varieties has emerged as the most vital input for enhancing pulses production in India. U.P. plays an important role in pulses production by contributing about $9.0 \%$ to the total pulses production of the country. Among pulses, chickpea contribute maximum (28\%) followed by lentil (22\%), urdbean (16\%) pigeonpea (14\%) and moongbean (2) in the total production of pulses in U.P. The 7 districts of Bundlekhand viz., Banda, Chitrakoot, Jalaun, Mahoba, Hamirpur, Lalitpur, and Jhansi are famous for pulses cultivation and these areas are consider as pulse bowl in the country. Chickpea crop contributes maximum to the total pulses production in the state. Even though, the area and production of pulses in the state decline continuously since 1990s due to promotion of paddy-wheat cropping system and irrigation. The advancement in pulses production technologies has further opened a new hope to increase the production and productivity of the pulses in different irrigated and rainfed agro eco-systems of states.

\section{Causes of low productivity}

There are numerous reasons for low productivity in agriculture. The causes of low productivity are as follows:

\section{Extreme pressure of population on land}

India has veteran unexpected population growth between 2001 and 2011. In 2050
India's population is projected to be 1.69 billion [4]. The increasing population is largely responsible for fragmentation of land holdings, subdivision that results into low productivity of land.

\section{Land degradation and uneconomic land holdings}

Soil is a vital resource and nutritional erosion in soil is a serious problem, which leads to depletion of soil health. This is only because of deforestation and mismanaged agricultural practices. Boost up in salinity and alkalinity is because of mismanagement and intensified use are other reasons for loss of soil fertility. Also the excess unscientific methods of irrigation further harm the fertility levels of the soil.

As per Agriculture Census 2010-11, marginal and small holdings ( $<2$ ha.) account for $85 \%$ of the total operational holdings and $44 \%$ of the total operated area. Small farm sizes inhibit mechanization. This creates difficulties in application of contemporary inputs, embracing of scientific land improvement, water conservation and plant protection measures. Consolidation of land can help improvement in productivity [10].

\section{Uncertain monsoons and insufficient irrigation amenities}

In $2000-01$ about $43.4 \%$ of the cultivated land had irrigation facilities. Not surprisingly, Indian farmers are still exposed to the vagaries of the monsoons. Indian agriculture is therefore truly remarked as a gamble against monsoon.

With more than half of the gross cropped area being rainfed, failure or inadequacy of rains causes fluctuation in yields. Need to develop rainfed agriculture on scientific appearance. 
Incapability to use of high yielding variety Seeds

High yielding varieties requires lots of water in addition to fertilizers and pesticides support, which becomes more risky due to the absence of assured irrigation facility and uncertain monsoons. The efficiency of inputs e.g. fertilizers, pesticides and irrigation is mainly gritty by the quality of the seed used. It is reported that quality of seed accounts for $20-25 \%$ of productivity. Thus timely availability of quality seeds at reasonable prices to farmers is necessary for achieving higher productivity and production [11].

\section{Imbalance use of fertilizers}

Unstable use of fertilizers is one of the important reasons for low productivity and depleting soil fertility. The average N: P: K ratio in the past two decades has been 7:3:1 against recommended 4:2:1[6].

\section{Occurrence of insect-pests and diseases}

Insect-pests, diseases and weeds are the major factors which are limiting productivity. Pests are one of the major determinants for achieving higher production in agriculture crops. It is estimated that harbouring insects consume about $26 \%$ of the potential production. $30 \%$ crop loss in India is recording every year due to insect-pests and diseases. This loss is up to $40 \%$ in vegetable production. The production losses have shown an increasing trend over the years after year. In 1983, the losses due to insect-pests were estimated worth Rs 6,000 crores which increased to Rs 29,000 crores in 1996 [7].

\section{Farm mechanization}

Mechanization in agriculture is necessary input in present agriculture. It enhances productivity, also reducing human drudgery and cost of cultivation. At present the farm power availability is $1.84 \mathrm{~kW} \mathrm{ha}^{-1}$ (2013-14) which is to increased $4.0 \mathrm{~kW} \mathrm{ha}^{-1}$ by 2022 [5], still there are many parts in country where farm operations are depending on human labour and animal, which significantly reduces the productivity.

\section{Subsistence nature of farming}

Indian agriculture is categorized by its subsistence nature, i.e., most of the produce is directly consumed by producers and surplus, if any, is generally low. This is since most Indian farmers, being poor, use out of use implements and technology, and are not able to afford costly inputs. This results in low returns and meager incomes, which in turn means less savings and reinvestments.

\section{Social environment}

The social environment in terms of irrational attitude, illiteracy and impassive behaviors towards the adoption of new technologies is also a major limiting factor to the improvement in the agricultural productivity.

\section{Flaw in policy perspectives}

Due to a number of economic and political compulsions, the strategies for agricultural growth remained anxious with the aim of achieving rapid increases in food grains production by concentrating the resources and efforts on the relatively better-endowed areas and strata of cultivators.

\section{Potential productivity in pulses and} Possibilities for future

Abiotic stresses leading to sub-optimal nutrient uptake, use of low doses of fertilizer /nutrients are the major culprit in pulse production. However, wide range of agroclimatic conditions, temperature appropriation 
in almost round the year for farming and availability of adequate rainfall indicates to the fact that there is a immense potential to improve productivity of pulses. Technologies could be potentially used for increasing pulses production and productivity can be classified as

(A) Horizontal approach

(B) Vertical approach and

(C) Policy constraints, credit and marketing

\section{Horizontal approach}

Replacement of low productivity crops with pulses and efficient utilization of rice fallow lands

Primarily rainfed conditions existing in the states of Eastern Bihar, Uttar Pradesh, M. P., Chhattisgarh, Orissa, W. B. and Jharkhand are the potential are of pulse production. About $25 \%$ of this area has potential for strengthening Rabi pulses next to paddy depending on soil conditions agreeing that additional 3 to 4 million ha area can be brought under Rabi pulses. Need to encourage farmers' through various incentives and region specific strategies for cultivation of pulses in the identified districts. Essential technological support in terms of suitable short duration varieties, dose of nutrient application and other agronomic practices should come from confined research stations. wheat crop should be replaced by Rabi pulses such as chickpea whereas, barley and mustard should be replaced by lentil. Harvested rain water should be used for Rabi crop as life saving irrigation [14].

\section{Vertical approach}

Potential techniques and methods should be discussed to achieve more production without increase in crop area. Focus should be to improve crop productivity unit ${ }^{-1}$ area.
Following vertical approach can be efficiently and effectively utilized for increasing pulses productivity.

\section{Encourage sequential / inter cropping and Utera cultivation of pulses}

Excellent number of promising sequential/ inter cropping systems for pulses have been developed by Agricultural Research Stations as shown in Table 1 whereas, promising intercropping for different pulse producing states are presented in Table 2.

Farmers in rainfed conditions are practicing them in traditional ways. The practices for rainfed states should include:-

a) Identification of district wise promising intercropping pattern for each agro climatic zone and targeting of area coverage accordingly.

b) Field demonstrations on intercropping in participatory mode.

c) Ensuring availability of seed of pulse varieties suitable for intercropping.

d) Demonstration of suitable animal drawn and tractor drawn seeding devices for main and intercrop as well.

e) Seed-minikits of pulses should be distributed to farmers opting for intercropping only.

f) KVKs should be involved in training of farmers and field demonstration of production technology [13].

\section{Seed replacement rate / multiplication strategy}

Productivity increment in pulses is possible with incorporation of new HYVs to achieving maximize the yields. The major issue is timely availability of quality seeds and its' popularization of promising varieties to the farmers in adequate quantities. Use of good quality/certified seeds in pulses is insufficient. 
Hence efforts should be made in this direction through various Government sponsored programmes such as National Food Security Mission, (NFSM), Integrated Scheme of Pulses, Seed Village Programme etc. These efforts have been successful in order to increase SRR of pulses to $22.5 \%$ by the year 2010-11[2].

\section{Adoption of preeminent agronomic practices}

Tillage, plant population, crop geometry, seed treatment (fungicides) and crop-specific bacterial cultures, sowing methods and time, nutrient and water (rainwater and irrigation) management, weed management and plant protection are major agronomic practices having impact on y pulse productivity [12].

\section{Balance nutrient management}

Indian pulse growing soils are deficient in micro nutrients such as $\mathrm{Zn}, \mathrm{S}$ and $\mathrm{B}$ in major pulse growing areas. Sulphur application @ 20-40 kg ha ${ }^{-1}$ (through gypsum/ SSP) at sowing time whereas, zinc sulphate @ 25-50 $\mathrm{kg} \mathrm{ha}^{-1}$ once in two years could effectively revoke the problem and help in maximization of crop productivity (Singh et al., 2013d). Weed infestation in pulses was observed to cause heavy yield losses in pluses for this issue number of cost-effective herbicides are available in the market that can be popularized for optimizing pulses production [17].

\section{Resource conservation technologies for expansion of irrigation using}

Moisture stress conditions are most suitable for growing of Pulses crops. Scheduling of irrigation, estimation of quantity of water to be applied and water saving irrigation methods may be useful to increased yield. Use of Drip irrigation and sprinkler irrigation has huge potential for saving irrigation water and expanding area under irrigated conditions.

\section{Efficient insects-pests and diseases management}

In the present era of climate change, it is important that region specific advisories should be issued for guiding pulse growers on disease and pest control. Though, pulse crops are very sensitive to many insect-pests and diseases, a major cause of concern are its incidence if not under control may demolish the entire crop. Similarly Fusarium wilt is wide spread in pulses growing regions. In addition, legumes grains are being significantly damaged by pests during storage. Similarly pod borer, aphids and wilt (Fusarium lentis) are major insects and diseases [15].

\section{Farm mechanization}

Different agro-climatic zones and soil types are suitable for pulse production. Mechanization is essential tool for increment in productivity. Besides mechanization adoption of deep ploughing, ridge/ line sowing and inter-culture operations contributes to reduction in cost of production and improves resource use efficiency (inputs, water and energy) [9]. Considering small holdings of farmers, custom hiring of implements / machines is only suitable option for increasing the reach of farm mechanization.

\section{Post-harvest handling of grains to reduce loss}

Mechanized threshing is essential to be promoted with provision of incentives for purchase of threshers. Mini dal-mills should be promoted and popularized by various efforts including incentives. Private sector should be involved for encouragement to establish dal mills in districts/ rural areas with 
large acreage under pulses. Private companies need to be promoted in processing, packaging and marketing of pulses.

\section{Suitable extension approaches for adoption of improved pulse production techniques}

Improved pulse production techniques should be popularized and not only on the basis of region/agro-climatic, but should also be matching with resource-base of the farming community [16]. Aggregation of produce of scattered pulses farmers and linking them with the business for quality inputs and for efficient marketing of the produce need to be established. Similarly, efficient extension strategy should be adopted for upliftment of socio-economic status of farmers [17].

Table.1 Sequential / inter cropping system of pulses

\begin{tabular}{|l|l|}
\hline \multicolumn{1}{|c|}{ Sequential cropping } & \multicolumn{1}{c|}{ Intercropping System } \\
\hline Pulses in rice fallow & Cereals + Pulses (Wheat/Barley + Lentil/Chickpea) \\
Rabi pigeonpea & Oilseeds + Pulses (Linseed/Mustard + Lentil/ \\
Summer oilseed and pulses & Chickpea) \\
Summer moong bean + pigeonpea & Pulses + Pulses (Chickpea + Lentil / Fieldpea) \\
Late sown chickpea in irrigated area & Sugarcane + Pulses (Moongbean / Urdbean) \\
\hline
\end{tabular}

Table.2 Promising intercropping system for different pulses growing states

\begin{tabular}{|l|l|}
\hline \multicolumn{1}{|c|}{ Pulses growing states } & \multicolumn{1}{c|}{ Intercropping system } \\
\hline U.P., Gujarat, Rajasthan & Moongbean / Cowpea \\
\hline $\begin{array}{l}\text { U.P., Andhra Pradesh, Maharashtra, T. N., } \\
\text { Karnataka, }\end{array}$ & Sugarcane + Cowpea/Moongbean / Urdbean \\
\hline $\begin{array}{l}\text { Punjab, Haryana, M. P., Gujarat, } \\
\text { Maharashtra, Andhra Pradesh, }\end{array}$ & Cotton + Moongbean / Urdbean / Cowpea \\
\hline Bihar, Maharashtra, M. P., Karnataka, & Groundnut / Sorghum / Pearlmillet + Urdbean \\
\hline Maharashtra, Madhya Pradesh, & Soybean + Pigeonpea \\
\hline $\begin{array}{l}\text { Gujarat, Karnataka, Andhra Pradesh, } \\
\text { Maharashtra }\end{array}$ & Pearl millet/sorghum + Pigeon pea \\
\hline
\end{tabular}

\section{Management of blue bull}

Pulse crops are vulnerable to be attacked by Blue bulls in the Indo-Gangetic Plains. Because of the widespread danger particularly in Uttar Pradesh, Bihar, Madhya Pradesh, Punjab, Haryana, Rajasthan Gujarat and Chhattisgarh the potential area suitable for taking pulses crops is left uncultivated by the farmers.

Due to this pulse growers are suffering with heavy economic losses. Unfortunately there is no viable strategies are available in the country for effective control of this menace.

\section{Policy constraints, credit and marketing of pulses}

In general marginal and small farmers are involved in pulses cultivation. They are running with poor credit and marketing facilities. They fall under resource poor category and having less risk-bearing capacity. Release of credit to such farmers is also not hustle-free. Marketing network in remote areas are not appropriate. Fictional or in-effective procurement of produce by a committed agency is also point of concern. Delivery of improved technology, inputs, credits need to be stream lined through 
appropriate policy interventions. Advantage of crop insurance need to be extended to pulses farmers.

In conclusion, a holistic approach is required to enhance the production and productivity of pulses crop rather than a single approach method. Prominently good agronomic practices (gap) with their different components for excelling production under changing climatic scenario, necessitate aggregation of all the components of advocated technologies as an unit not with selection of few of them leading to numerous complications, soil health hazards and half hearted response of technologies in question. Recourses should be taken on priority basis for improving pulse productivity are:

Hasty adoption of advance technologies for bridging the yield gap.

Scheduling and strengthening of life saving irrigation in pulse growing areas.

Timely availability of critical inputs viz., seed, fertilizer, pesticides.

Institutional support for enhancement of variety/ seed replacement rate and quality production as well.

Steady mechanization for pulse production and storage.

Public-private partnership for sustaining value chain and minimizing post-harvest losses.

Policy support for value addition and balancing chain for pulses production and marketing.

\section{References}

1. Ali M and Gupta S. 2012. Carrying capacity of Indian agriculture: Pulse crops Cur. Sci.; 102(6):874-81.

2. Anonymous. 2013. Report of Expert Group on Pulses. Department of Agriculture \& Cooperation Government of India, Ministry of Agriculture.139.
3. Chauhan J S, Singh B B and Gupta S. 2016. Enhancing pulses production in India through improving seed and variety replacement rates. Indian J. Genet., 76(4): 1-10.

4. Goswami, R. 2013. India's population in 2050: extreme projections demand extreme actions. East Asia forum, Economics, Politics and Public Policy in East Asia and the Pacific.

5. http://agricoop.nic.in/divisiontype/mechan ization-and-technology.

6. International Market Assessment, India, Indian agriculture challenges and Prospects, 2009.

7. Kiruthika, N. 2013. Department of Agricultural Economics Tamil Nadu Agricultural University, Adoption of Integrated Pest Management (IPM) in Vegetables: A case of onion In Tamil Nadu, India.

8. Mundhe, F. 2015. Agricultural productivity in India: trends during five year Plans. M. K. College, Kalyan, India. The Business \& Management Review, 5:4.

9. Patel A K, Singh D, Baghel K S and Pandey A K. 2014. Enhancing Water Productivity to Improve Chickpea Production in Bansagar Command Area of Madhya Pradesh. Journal of AgriSearch 1(1): 19-21.

10. Rajan, G. U. 2015. Sustainable Agriculture Enthusiast, Why does India have such Low agricultural productivity? (quora.com).

11. State of the Indian Agriculture, 2012-13. Government of India, Ministry of Agriculture, Department of Agriculture and Cooperation, New Delhi, pp. 1-247.

12. Singh A K, Singh D, Singh A K, Gade R $M$ and Sangle U R.2012c. Good Agronomic Practices (GAP) - An efficient and eco-friendly tool for sustainable management of plant diseases under changing climate scenario. J. Plant Disease Sci. 7 (1):1-8. 
13. Singh AK, Singh KA, Bharati RC and Chadra N.2013e. Response of intercrops and nutrient management on the performance of tobacco based intercropping system and assessment of system sustainability. Bangladesh J. Bot. 42(2): 343-348.

14. Singh, A. K., Singh, S. S., Prakash, V., Kumar, S. and Dwivedi, S. K. 2015. Pulses Production in India: Present Status, Bottleneck and Way Forward. Journal of Agrisearch. 2(2): 75-83

15. Singh D, Kumar A, Singh A K, Tripathi H S. 2013. Severity of chickpea wilt in north Bihar and nutritional studies on
Fusarium oxysporum $f$. sp. Ciceri J. Plant Disease Sci.; 8(2):137-140.

16. Singh D, Patel AK, Baghel SK, Singh MS, Singh A and Singh AK. 2014a. Impact of Front Line Demonstration on the Yield and Economics of Chickpea (Cicer arietinumL.) in Sidhi District of Madhya Pradesh. Journal of Agri Search 1(1): 22-25.

17. Singh S S, Singh A K and Sundaram P K. 2014b. Agrotechnological options for upscaling agricultural productivity in eastern indo gangetic plains under impending climate change situations: A review. Journal of Agri search 1 (2): 5565.

\section{How to cite this article:}

Ambreesh Singh Yadav, Sujit Kumar, Narendra Kumar and Hardev Ram. 2019. Pulses Production and Productivity: Status, Potential and Way Forward for Enhancing Farmers Income. Int.J.Curr.Microbiol.App.Sci. 8(04): 2315-2322.

doi: https://doi.org/10.20546/ijcmas.2019.804.270 